Care: Jurnal Ilmiah Ilmu Kesehatan Vol .8, No.2, 2020, hal 168-175

Tersedia online di https://jurnal.unitri.ac.id/index.php/care

ISSN 2527-8487 (online)

ISSN 2089-4503 (cetak)

\title{
RIWAYAT USIA PERTAMA MENARCHE $\leq 12$ TAHUN BERHUBUNGAN DENGAN KEJADIAN KANKER PAYUDARA PADA WANITA USIA SUBUR
}

\author{
Siwi Ariana ${ }^{1)}$, Selamat Budijitno ${ }^{2)}$, Suhartono ${ }^{3)}$ \\ ${ }^{1)}$ Magister Epidemiologi Sekolah Pascasarjana Universitas Diponegoro Semarang \\ ${ }^{2)}$ Fakultas Kedokteran Universitas Diponegoro Semarang \\ ${ }^{3)}$ Fakultas Kesehatan Masyarakat Universitas Diponegoro Semarang \\ E-mail: siwi.ariana@yahoo.co.id
}

\begin{abstract}
Breast cancer is a continuous cell growth that spreads without control in breast tissue. Young women especially those who are in reproductive ages with breast cancer tend to have more malignant cancer and worse prognosis. The purpose of this study is to prove history of first age menarche $\leq 12$ years associated with the incidence of breast cancer in reproductive ages. Research design analytic observational study used a control case study design. The population in this study were reproductive women aged 15-49 years who were examined at the Oncology clinic in Tugurejo General Hospital with anatomical pathology results. The samples in this study were 42 cases and 42 controls with consecutive sampling technique. The data were analyzed univaraiate anda bivariate by chi-square. Results research history of first age menarche $\leq 12$ years releted of breast cancer with value $p=$ 0,005; $O R=4,015 ; 95 \% C I=1,618-9,966$. Conclusion history of the first age of menarche $\leq 12$ years is related to the incidence of breast cancer in women of childbearing age. The researchers can add new variables about risk factors for breast cancer.
\end{abstract}

Keywords : Breast cancer; history of first age menarche $\leq 12$ years.

\begin{abstract}
ABSTRAK
Kanker payudara merupakan pertumbuhan sel yang terus menerus dan menyebar tanpa kendali pada jaringan payudara. Wanita usia muda terutama wanita usia subur dengan kanker payudara cenderung lebih ganas dan prognosis lebih buruk. Tujuan penelitian ini untuk membuktikan riwayat usia pertama menarche $\leq 12$ tahun berhubungan dengan kejadian kanker payudara pada wanita usia subur. Desain penelitian observasional analitik menggunakan desain studi kasus kontrol. Populasi dalam penelitian ini adalah wanita usia subur berusia 15-49 tahun yang periksa di poli Onkologi di RSUD Tugurejo dengan hasil
\end{abstract}

Cara mengutip: Ariana, Siwi., Budijitno, Selamat., \& Suhartono. (2020). Riwayat Usia Pertama Menarche $\leq 12$ Tahun Berhubungan Dengan Kejadian Kanker Payudara Pada Wanita Usia Subur. Care:Jurnal Ilmiab Ilmu Kesehatan, 8(2), 168-175 
patologi anatomi. Sampel dalam penelitian ini 42 kasus dan 42 kontrol dengan teknik consecutive sampling. Data dianalisis univariat dan bivaraiat dengan chi-square. Hasil penelitian menunjukan riwayat usia pertama menarche $\leq 12$ tahun berhubungan terhadap kejadian kanker payudara pada wanita usia subur dengan nilai $p=0,005 ; \quad$ OR $=4,015 ; 95 \%$ $\mathrm{CI}=1,618-9,966$. Kesimpulan riwayat usia pertama menarche $\leq 12$ tahun berhubungan terhadap kejadian kanker payudara pada wanita usia subur. Bagi peneliti selanjutnya dapat menambah variabel baru tentang faktor risiko kanker payudara.

Kata Kunci : Kanker payudara; Riwayat usia pertama menarche $\leq 12$ tahun.

\section{PENDAHULUAN}

Kanker payudara atau tumor ganas disebabkan oleh sel yang membelah secara terus menerus ada pada jaringan payudara, kelenjar epitel, lobules, jaringan lemak, atau pembuluh darah pada payudara (Rasjidi I, 2010). Sel yang membelah diakibatkan karena mutasi dari kerusakan DNA (Deoxyribo Nucleic Acid), menyerang jaringan biologis seperti pada jaringan terdekat (invansi) atau pada jaringan yang jauh (metastasis) (WHO, 2015).

Menurut WHO tahun 2015 kasus kanker payudara merupakan penyebab kematian ke 5 dari semua kanker di dunia dengan angka mortalitas 571.000 orang (WHO, 2015). Data GLOBOCAN (Global Burden of (ancer) kasus baru kanker payudara pada tahun 2012 sebanyak 1.670 .000 dengan kematian 522.000 jiwa (52\%) dari semua kasus kanker. Kasus kanker payudara di Negara maju sebanyak 794.000 dengan angka kematian 198.000 jiwa (59\%) lebih banyak dibandingkan dengan kejadin kansus kanker di Negara berkembang sebanyak 883.000 dengan kematian 324.000 jiwa (53\%) (WHO,2012). Negara berkembang dengan kasus kanker payudara tertinggi di Asia (Asia timur dan Tenggara). Kanker payudara di Asia pada tahun 2012 sebanyak 639.824 jiwa. Indonesia menduduki urutan ke 4 dengan kasus kanker payudara sebesar 48.998 kasus (Ghoncheh M, Momenimovahed Z, and Salehiniya, 2016).

Kasus kanker payudara Indonesia pada tahun 2013 merupakan penyebab kematian kanker ke 2 pada wanita setelah kanker serviks. Kasus kanker payudara sebesar 40,3 per 100.000 perempuan atau sekitar 48.998 kasus baru per tahun dengan mortalitas 16,6 per 100.000 penduduk. Estimasi kanker payudara tertinggi di Provinsi Jawa Tengah sebanyak 11.511 jiwa (Kemenkes RI tahun 2015).

Berdasarkan data profil Provinsi Jawa 
Tengah tahun 2017 untuk deteksi dini kanker payudara dengan Clinical Breast Examination (BCE) kasus tertinggi di temukan di kabupaten Kendal (50,62\%) dan Semarang (13,33\%) (Dinkes Jateng, 2017). RSUD Tugurejo Semarang merupakan salah satu rumah sakit di Provinsi Jawa Tengah yang berada di perbatasan antara Semarang dan Kendal. Kanker payudara di RSUD Tugurejo Semarang tahun 2015 sebanyak 223 kasus, tahun 2016 sebanyak 343 kasus, tahun 2017 kasus sebanyak 445 orang dan tahun 2018 sampai dengan bulan Juli kasus sebanyak 444 orang (RSUD Tugurejo, 2015-2018).

Kanker payudara lebih banyak terjadi pada wanita dibandingkan pria dengan perbandingan 100:1 (Suyatno dan Pasaribu E,2014). Kanker payudara merupakan penyebab utama kematian pada usia $>60$ tahun dan risiko terbesar usia 75 tahun (Sastro Sudarmo, 2012). Kanker payudara juga dapat menyerang semua usia termasuk wanita usia muda. Wanita dengan usia muda dengan terdiagnosa kanker payudara akan lebih agresif dan prognosis yang lebih buruk dari pada orang yang lebih tua termasuk wanita usia subur (Kurnia A H, 2010).

Kanker payudara merupakan penyakit mutifaktorial. Menarche dini merupakan salah satu faktor risiko kanker payudara beberapa penelitian menyatakan bahawa menarche $<12$ tahun berisiko 2,08 kali untuk terkena kanker payudara dibandingkan dengan menstruasi $>12$ tahun (Jesse N. Nodor a, 2014). Berdasarkan penelitian Puspitasari R, menyatakan bahwa prevalensi menarche dini semakin banyak dan 20\% terjadi di daerah urban (Puspita R, 2016). Menarke diakibatkan oleh beberapa faktor seperti obesitas, kelebihan berat badan, dan status gizi yang baik. Menarche awal juga banyak ditemukan anak-anak dengan sosial ekonomi tinggi, telah terpapar oleh media audio visual, kurang aktivitas fisik dan persentase lemak tubuh yang tinggi ( Sukarni K dan Margareth, 2013). Oleh karena itu peneliti tertarik untuk mengatahui hubungan antara riwayat usia pertama menarche $\leq 12$ tahun dengan kejadian kanker payudara pada wanita usia subur di RSUD Tugurejo Semarang.

\section{METODE PENELITIAN}

Desain peneletian observasional analitik, dengan studi case-control. Populasi penelitian dibagi menjadi dua yaitu populasi kelompok kasus dan populasi kelompok kelompok kontrol dengan perbandingan 1:1. Populasi studi kelompok kasus pada penelitian ini adalah 
semua wanita usia subur yang dinyatakan menderita kanker payudara ganas dengan hasil PA (+) di RSUD Tugurejo Semarang. Populasi studi kelompok kontrol pada penelitian ini adalah penderita kanker payudara jinak dengan hasil PA (-) di RSUD Tugurejo Semarang. Sampel dalam penelitian ini sebanyak 84 responden dengan 42 kasus dan 42 kontrol. Instrument yang digunakan dalam penelitian ini adalah kuesioner yang sudah standar. Data yang diperoleh dianalisis secara statistik dengan analisis univariat dan bivariat dengan menggunakan uji Chi-Square dengan tingkat signifikansi ditetapkan pada 0,05. Penelitian ini telah ditinjau dan disetujui oleh Komite Etik Penelitian Kesehatan (KEPK) RSUD Tugurejo Semarang dengan Ethical clearance nomor 103/KEPK/X/2018. Waktu Penelitian selama 3 bulan dari bulan Oktober-Desember 2019.

\section{HASIL}

Tabel 1. Distribusi bedasarkan usia Wanita Usia Subur (WUS)

\begin{tabular}{|c|c|c|c|c|}
\hline \multirow{3}{*}{ Usia } & \multicolumn{4}{|c|}{ Kanker Payudara } \\
\hline & \multicolumn{2}{|r|}{ Kasus } & \multicolumn{2}{|l|}{ Kontrol } \\
\hline & $\mathrm{n}=42$ & $(\%)$ & $\mathrm{n}=42$ & $(\%)$ \\
\hline$\geq 40$ tahun & 12 & 28,6 & 26 & 61,9 \\
\hline \multirow[t]{5}{*}{$<40$ tahun } & 30 & 71,4 & 16 & 38,1 \\
\hline & Mean & : 42,11 & Mean & : 36,88 \\
\hline & Median & $: 43,50$ & Median & $: 38,0$ \\
\hline & $\mathrm{SD}$ & $: 6,78$ & $\mathrm{SD}$ & $: 9,00$ \\
\hline & Min-max & $: 17-49$ & Min-max & : 18-49 \\
\hline
\end{tabular}

Berdasarkan Tabel 1 distribusi usia kejadian kanker payudara banyak terjadi pada usia $\geq 40$ tahun sebesar 28,6\% sedangkan kelompok kontrol sebesar 61,9\%. Kelompok kasus yang menderita kanker payudara memiliki nilai mean 42,11 , median 43,50, SD 6,78 dan usia minimal 17 tahun dan maksimal 49 tahun. Sedangkan pada kelompok kontrol memiliki nilai mean 36,88, median 38,0,
SD 9,00 dan nilai minimal 18 tahun dan maksimal 49 tahun.

Berdasarkan Tabel 2 menunjukkan bahwa tingkat pendidikan responden lebih banyak pada pendidikan lulusan SMA dengan proporsi pendidikan pada kelompok kasus sebesar 28,6\% dan kelompok kontrol sebesar 42,9\%. 
Care: Jurnal Ilmiah Ilmu Kesehatan Vol .8, No.2, 2020, hal 168-175

Tabel 2. Distribusi pendidikan Wanita Usia Subur (WUS)

\begin{tabular}{|c|c|c|c|c|}
\hline \multirow{3}{*}{ Tingkat pendidikan } & \multicolumn{4}{|c|}{ Kanker Payudara } \\
\hline & \multicolumn{2}{|c|}{ Kasus } & \multicolumn{2}{|l|}{ Kontrol } \\
\hline & $\mathrm{n}=42$ & $\%$ & $\mathrm{n}=42$ & $\%$ \\
\hline Tidak sekolah & 1 & 2,4 & 2 & 4,8 \\
\hline Tamat SD & 12 & 28,6 & 8 & 19,0 \\
\hline Tamat SMP & 12 & 28,6 & 10 & 23,8 \\
\hline Tamat SMA & 12 & 28,6 & 18 & 42,9 \\
\hline D3 & 2 & 4,8 & 1 & 2,4 \\
\hline Tamat PT & 3 & 7,1 & 3 & 7,1 \\
\hline
\end{tabular}

Berdasarkan Tabel 3 menunjukan jenis kelompok kasus 42,9 \% dan kelompok pekerjaan responden responden yang kontrol 35,7.

didominasi oleh pekerjaan swasta pada

Tabel 3. Distribusi pekerjaan wanita Usia Subur (WUS)

\begin{tabular}{lccccc}
\hline \multirow{2}{*}{ Tingkat pendidikan } & \multicolumn{5}{c}{ Kanker Payudara } \\
\cline { 2 - 6 } & \multicolumn{3}{c}{ Kasus } & Kontrol & $(\%)$ \\
\cline { 2 - 6 } & $\mathrm{n}=42$ & & $(\%)$ & $\mathrm{n}=42$ & 21,4 \\
Tidak Bekerja & 2 & 4,8 & 9 & 32,1 \\
Ibu Rumah tangga & 13 & 31,0 & 14 & 35,7 \\
Swasta & 18 & 42,9 & 15 & 9,5 \\
Wiraswasta & 7 & 16,7 & 4 & 0,0 \\
PNS & 1 & 2,4 & 0 & 0,0 \\
Lainnya & 1 & 2,4 & 0 & \\
\hline
\end{tabular}

Tabel 4. Hubungan riwayat usia pertama menarche $\leq 12$ tahun dengan kejadian kanker payudara pada wanta usia subur (WUS)

\begin{tabular}{|c|c|c|c|c|c|c|c|}
\hline \multirow{3}{*}{$\begin{array}{c}\text { Riwayat usia } \\
\text { pertama } \\
\text { menarche }\end{array}$} & \multicolumn{4}{|c|}{ Kanker Payudara } & \multirow{3}{*}{ p Value } & \multirow{3}{*}{ OR } & \multirow{3}{*}{$95 \% \mathrm{CI}$} \\
\hline & \multicolumn{2}{|c|}{ Kasus } & \multicolumn{2}{|c|}{ Kontrol } & & & \\
\hline & $n=42$ & $\%$ & $\mathrm{n}=42$ & $\%$ & & & \\
\hline$\leq 12$ tahun & 27 & 64,3 & 13 & 31,0 & $<0,005$ & 4,015 & $1,618-9,966$ \\
\hline$>12$ tahun & 15 & 35,7 & 28 & 69,0 & & & \\
\hline
\end{tabular}

Tabel 4. Menunjukkan bahwa proporsi responden yang mengalami riwayat usia pertama menarche $\leq 12$ tahun pada kelompok kasus $(64,3 \%)$ lebih besar dibandingkan kelompok kontrol (31,0\%). Berdasarkan hasil analisis bivariat terdapat hubungan yang bermakna antara riwayat usia pertama mengalami menarche $\leq 12$ tahun dengan kejadian kanker payudara (nilai $p<0,005)$. Hal ini menunjukkan bahwa riwayat usia pertama mengalami menarche $\leq 12$ tahun merupakan faktor risiko kejadian kanker payudara pada wanita $\quad(\mathrm{OR}=4,015, \quad 95 \% \quad \mathrm{CI}=$ 
1,618-9,966). Kesimpulan bahwa wanita yang memiliki riwayat usia pertama mengalami menarche $\leq 12$ tahun berisiko 4,015 kali untuk terkena kanker payudara dibandingkan yang riwayat usia pertama mearche $>12$ tahun.

\section{PEMBAHASAN}

Usia normal orang mengalami mestruasi atau keluarnya darah dari kemaluan saat berusia 13 tahun (Guyton dan Hall, 2007). Berdasarkan usia menarche dibagi menjadi tiga kelompok yaitu menarche dini usia $\leq 12$ Tahun, menarche normal 13-15 tahun dan menarche lambat $>16$ tahun (Joison, 2018). Hasil penelitian menunjukan responden yang mengalami riwayat usia pertama menarche $\leq 12$ tahun pada kelompok kasus (64,3\%) lebih besar dibandingkan kelompok kontrol (31,0\%).

Kejadian Kanker Payudara berdasarkan analisis univariat menunjukan bahwa kejadian kanker payudara lebih banyak terjadi pada responden pada usia $\geq 40$ tahun sebesar 28,6\%. Hal ini dikarenakan masa laten dari kanker payudara yang lama sehingga timbul diusia $\geq 40$ tahun (Bustan MN, 2007). Hal ini dipengaruhi oleh tingkat pendidikan responden lebih banyak pada pendidikan lulusan SMA dengan proporsi pendidikan pada kelompok kasus sebesar 28,6\%. Pekerjaan responden yang didominasi oleh pekerjaan swasta pada kelompok kasus 42,9\%. Menurut Ross dan Mirowsky dalam penelitiannya menyimpulkan, adanya hubungan dari tingakat pendidikan dengan kesehatan. Waktu lamanya sekolah dapat mengembangkan kapasitas kehidupan yang efektif yang pada akhirnya akan mempengaruhi kesehatan, termasuk bekerja penuh-waktu, dapat menjalankan pekerjaan dengan baik, meningkatkan kesejahteraan, ekonomi, dapat mengontrol diri, lebih dapat mendukung sosial, dan bergaya hidup sehat (Ross, 1999).

Hubungan riwayat usia pertama menarche dengan kejadian kanker payudara, analisis bivariat didapatkan riwayat usia pertama menarche $\leq 12$ tahun dengan kanker payudara dengan nilai $\mathrm{p}<0,005$, maka terdapat hubungan yang bermakna antara riwayat usia pertama menarche $\leq 12$ tahun dengan kejadian kanker payudara. Riwayat usia pertama menarche $\leq 12$ tahun merupakan faktor risiko kejadian kanker payudara pada wanita usia subur di RSUD Tugurejo Semarang $(\mathrm{OR}=4,293$; $\mathrm{CI}=1,629-11,313)$.

Wanita yang mempunyai riwayat usia pertama menarche $\leq 12$ tahun berisiko 4,015 kali untuk terkena kanker payudara 
dibandingkan yang riwayat usia pertama menarche $>12$ tahun. Hal ini dikarenakan karena paparan hormon esterogen yang lebih cepat dan lama. Pada kelompok kasus usia pertama menarche lebih banyak terjadi pada usia menarche $\leq 12$ tahun dibandingkan pada kelompok kontrol yang mengalami menarche $>12$ tahun. Menarche terjadi karena hipotalamus menyekresikan hormon gonadotropin yang merangsang kelenjar pituitari untuk menghasilkan hormon FSH. Kelenjar pituitari merangsang ovarium untuk memproduksi hormon estrogen. Masa pubertas membuat hormon FSH yang disekresikan oleh kelenjar pituitari merangsang pematangan folikel di dalam ovarium sehingga merangsang ovarium menyekresikan hormon estrogen. Hormon estrogen dihasilkan saat menarche pertama kali (Suryaningsih, E.K., dan B.E. Sukaca, 2009).

Hasil ini sejalan dengan penelitian Dewi menyatakan bahawa usia menarche berisiko 3,492 kali untuk menderita kanker payudara. Menarche dini merupakan faktor yang berkaitan dengan kejadian kanker payudara karena paparan hormon estrogen dalam waktu yang lebih cepat (Dewi G A T, dan Hendrati Y L, 2015).Berdasarkan penelitian Ardiana wanita dengan menarche $\leq 12$ tahun berhubungan dengan kejadian kanker payudara dengan nilai $p=0,001$. Menarche $\leq 12$ tahun mengakibatkan kanker payudara karena paparan hormon estrogen yang lebih cepat mampu mengakibatkan rangsangan pada reseptor estrogen sehingga mengakibatkan sel kanker untuk membelah terus menerus (Ardiana,2013).

\section{KESIMPULAN}

Berdasarkan penelitian yang sudah dilakukan maka dapat disimpulkan bahwa riwayat usia pertama menarche $\leq 12$ tahun berhubungan dengan kanker payudara pada wanita usia subur. Wanita yang megalami riwayat usia pertama menarche $\leq 12$ tahun berisiko 4,015 kali untuk terkena kanker payudara dibandingkan yang usia menarche $>12$ tahun.

\section{SARAN}

Perlu adannya upaya pengendalian paparan horman esterogen dengan merubah gaya hidup dan faktor lain yang menyebabkan menstruasi dini.

\section{UCAPAN TERIMA KASIH}

Ucapan terima kasih penulis sampaikan kepada RSUD Tugurejo Semarang terutama petugas kesehatan di Poli Onkologi RSUD Tugurejo Semarang serta pihak yang telah membantu dalam 
penelitian ini, responden penelitian dan para informan. Ucapan terima kasih juga penulis sampaikan kepada keluarga dan semua rekan yang telah membantu dalam penyelesaian penelitian ini.

\section{REFERENSI}

Amirican Cencer Socielity. (2018) Breast Cancer Facts \& figures 2017-2018. Atlanta: American Cancer Socielity.

Ardiana, Negara H W, dan Sutisna M. (2013) Analisis Faktor Risiko Reproduksi yang Berbubungan dengan Kejadian Kanker Payudara pada Wanita. Kesehatan Kemenkes.

Bustan MN. (2007) Epidemiologi Penyakit Tidak Menular. Jakarta: Rineka Cipta.

Dewi G A T, Hendrati L Y. (2015) Analisis Risiko Kanker Payudara Berdasar Riwayat Pemakaian Kontrasepsi Hormonal Dan Usia Menarche. Jurnal Berkala Epidemiologi.

Dinas Kesehatan Jawa Tengah. (2017) Profil Kesehatan Provinsi Jawa Tengah Tabun 2016. Semarang: Dinas Kesehatan Jawa Tengah.

Edward and Emeritus C. (2004) The Breast Comprehensive Management of Benign and Malignant Disorders. America: Saunders.

Ghoncheh M, Momenimovahed Z, Salehiniya H. (2016) Epidemiology, Incidence and Mortality of Breast Cancer in Asia. Asian Pac J Cancer Prev. 2016;17(17):47-52.

Kementrian Kesehatan RI. (2015) Situasi Penyakit Kanker. Buletin Jendela Data dan Informasi Kesehatan. Jakarta: Kementrian kesehatan RI.

Kurnia A.H. (2010) Keajaiban Payudara. Jakarta: FKUI RSCM

Nodora JN, Gallo L, Cooper R, Wertheim BC, Natarajan L, Thompson PA, et al. (2014) Reproductive and Hormonal
Risk Profile According to Language Acculturation and Country of Residence in the Ella Binational Breast Cancer Study. J Women's Heal .

Ratna Puspitasari, Ari Udiyono, Lintang Dian Saraswati, Praba Ginanjar. (2016) Gambaran Usia Menarche Dini Di Pada Anak Sekolah Dasar Di Daerah Urban. Jurnal Kesehatan Masyarakat ISSN: 2356-3346.

Ross CE. J. Mirowsky. (1999) Refining the association between education and health: the effects of quantity, credentials, and selectivity. Demography, vol. 36, no. 4, pp. 445-460.

RSUD Tugurejo Semarang. (2018) Profil RSUD Tugurejo Semarang. 2017. Semarang : RSUD TUgurejo 2018.

Sastrosudarmo. (2012) Kanker The Silent Killer. Jakarta: Garda Media.

Sukarni K dan Margareth Z K. (2013) Kehamilan, Persalinan dan Nifas. Yogjakarta: Nuha Medika.

Suryaningsih, E.K., dan Sukaca B.E.(2009). Kupas Tuntas Kanker Payudara. Paradigma Indonesia. Yogyakarta: Pustaka Baru Press.

World Health Organization. (2012) Cancer Fact Sheets. Globocan 2012 [Internet]. 2012;0-5.

World Health Organization.Cancer [Internet]. 2018; Available from:bttp://www.who.int/news-room/f act-sheets/detail/cance., diakses 20 Maret 2017 jam 11.45 WIB.

Suyatno dan Prabu E. (2014) Bedah Onkologi Diagnosis dan Terapi. Jakarta: Sagung Seto. 